\section{Dysphagia in a young female patient: it's not always that simple}

\section{CLINICAL PRESENTATION}

A 42-year-old female patient was referred to our gastroenterology department with a 4-month history of weekly symptoms of dysphagia for solids and liquids. The patient also reported occasional symptoms of food impaction and heartburn. She denied nausea, vomiting, weight loss or a recent change in bowel habits. The patient was not under any medication. Medical or surgical history was unremarkable. There was no family history of gastrointestinal cancer. Physical examination was normal, and laboratory tests did not reveal anaemia or other abnormalities. She underwent an oesophagogastroduodenoscopy, and the oesophagus is shown in figure 1. Biopsies were performed in the upper and lower parts of the oesophagus and the result is shown in figure 2. Macroscopically and histologically, the stomach was normal. On the same day, the patient underwent a high-resolution manometry (HRM) (Medtronic 36-channel solid-state catheter) with 10 supine liquid swallows ( $5 \mathrm{~mL}$ water each) with the following findings (figure 3).

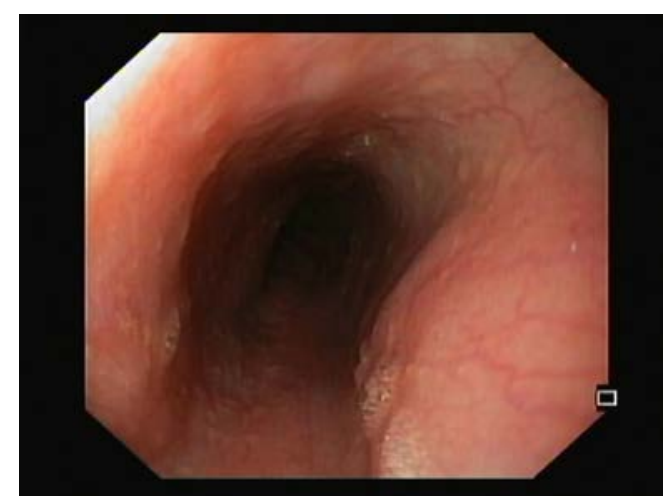

Figure 1 Endoscopic appearance of the oesophagus. Normal oesophageal mucosa with no identifiable lesions.

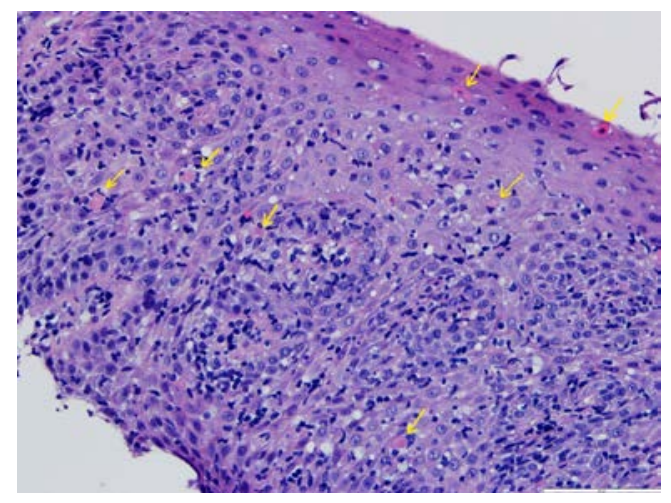

Figure 2 Histopathology slide showing the oesophageal mucosa $(\mathrm{H} \& \mathrm{E}, \times 200)$. There are numerous intraepithelial lymphocytes. Characteristic apoptotic and dyskeratotic squamous cells (civatte bodies) are seen scattered throughout the epithelium (arrows in yellow).

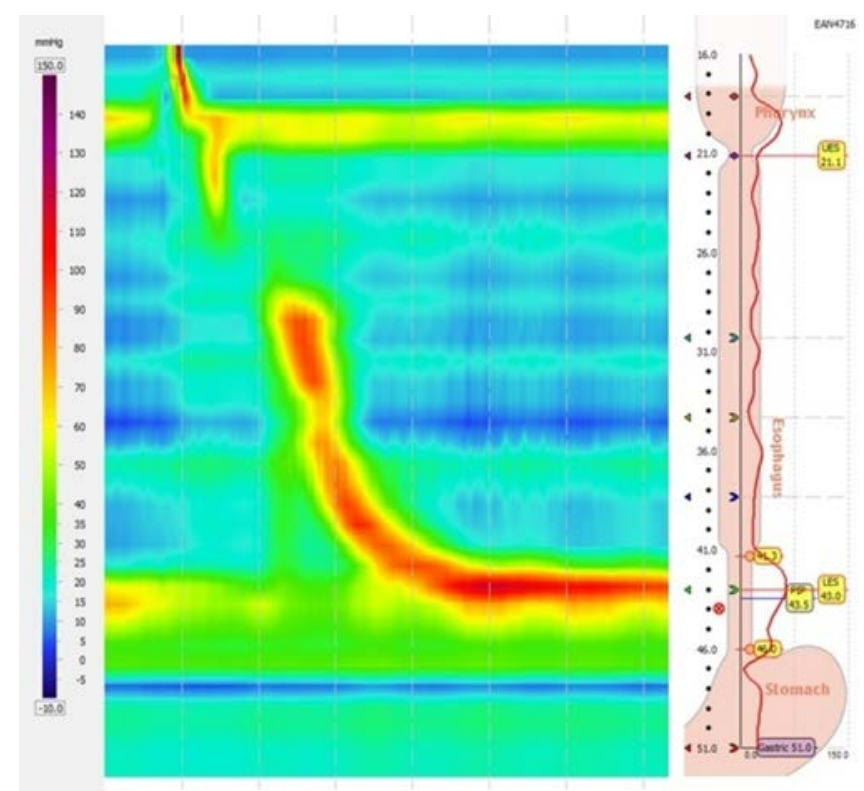

Figure 3 High-resolution manometry. Elevated integrated relaxation pressure $22.2 \mathrm{~mm} \mathrm{Hg}$ (cut-off $<15 \mathrm{~mm} \mathrm{Hg}$ ) and preserved peristalsis.

\section{QUESTIONS}

What is the diagnosis? How do we approach this patient? How is this treated?

\section{ANSWER}

This patient has lichenoid oesophagitis (LE). When LE is associated with lichen planus (LP) lesions and positive direct immunofluorescence (DIF) studies, it is defined as lichen planus oesophagitis (LPE). When LP lesions are absent and DIF studies are negative, it is defined as lichenoid oesophagitis pattern (LEP). ${ }^{1}$

Lymphocytic oesophagitis and LE may be in the same spectrum of disease since there are histological similarities, with the latter being distinguished by the presence of civatte bodies. ${ }^{1}$

LPE is more likely to occur in women, to progress to strictures and to be associated with rheumatological disorders, whereas LEP is more likely to affect the midoesophagus and to be associated with viral hepatitis and HIV infection. Both have a risk of neoplasia. ${ }^{1}$ In this case, DIF, autoimmune and virological studies were negative. Therefore, a diagnosis of LEP was made. An oesophagogastric

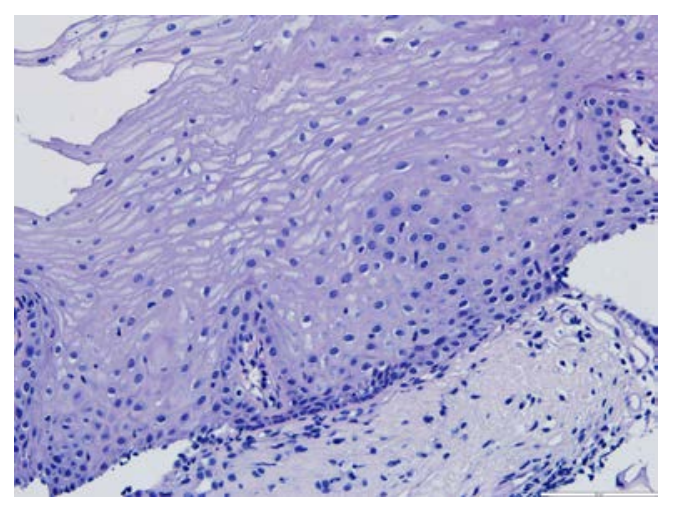

Figure 4 Histopathology slide showing the oesophageal mucosa $(H \& E, \times 200)$ under prednisolone $10 \mathrm{mg}$. Overall regression of the lymphocytic infiltrate can be seen. 


\section{Editor's quiz: GI snapshot}

junction outflow obstruction was seen on HRM. ${ }^{2}$ This is the first description of a manometric pattern associated with LE.

Treatment includes steroids and immunomodulators. ${ }^{1}$ A trial of oral prednisolone $40 \mathrm{mg}$ /day was started with complete resolution of symptoms. After 8 weeks, under $10 \mathrm{mg}$, there was a significant histological improvement (figure 4). HRM revaluation was also normal. Currently, the patient is asymptomatic under azathioprine $2.5 \mathrm{mg} / \mathrm{kg} /$ day.

The key learning points are performance of midoesophageal biopsies in selected cases of non-obstructive dysphagia, performance of DIF studies in LE and exclusion of related diseases.

\section{Joana Carvão $\odot,{ }^{1}$ Armando Peixoto, ${ }^{2}$ Elisabete Rios, ${ }^{3}$ Guilherme Macedo ${ }^{4}$}

${ }^{1}$ Gastroenterology, Hospital Central do Funchal, Funchal, Portugal

${ }^{2}$ Gastroenterology, Centro Hospitalar São João, Faculty of Medicine of the University of Porto, Porto, Portugal

${ }^{3}$ Histopathology, Centro Hospitalar São João, Faculty of Medicine of the University of Porto, Porto, Portugal

${ }^{4}$ Gastroenterology, Centro Hospitalar São João, Faculty of Medicine of the University of Porto, Porto, Portugal

Correspondence to Dr Joana Carvão, Gastroenterology Department, Hospital Central do Funchal, 9004-514 Funchal, Portugal; joanacarvao@hotmail.com

Contributors JC wrote the manuscript. JC, AP and ER reviewed the literature and collected the images. All authors edited the manuscript. JC is the article guarantor.
Funding The authors have not declared a specific grant for this research from any funding agency in the public, commercial or not-for-profit sectors.

Competing interests None declared.

Patient consent for publication Obtained.

Provenance and peer review Not commissioned; externally peer reviewed.

(c) Author(s) (or their employer(s)) 2019. No commercial re-use. See rights and permissions. Published by BMJ.

D) Check for updates

To cite Carvão J, Peixoto A, Rios E, et al. Gut Epub ahead of print: [please include Day Month Year]. doi:10.1136/gutjnl-2019-320307

Received 21 November 2019

Revised 10 December 2019

Accepted 14 December 2019

Gut 2019;0:1-2. doi:10.1136/gutjnl-2019-320307

ORCID iD

Joana Carvão http://orcid.org/0000-0003-2063-4257

\section{REFERENCES}

1 Salaria SN, Abu Alfa AK, Cruise MW, et al. Lichenoid esophagitis. Am I Surg Pathol 2013:37:1889-94.

2 Kahrilas PJ, Bredenoord AJ, Fox M, et al. The Chicago classification of esophageal motility disorders, v3.0. Neurogastroenterol Motil 2015;27:160-74. 